\title{
Low Prevalence of Occult Hepatitis B Infection Among Blood Donors in Beirut, Lebanon: Reconsider the Deferral Strategy of Anti-HBc Positive Blood Donors
}

\author{
Nour El Banna,, Tamima El Jisr, ${ }^{2}$ Hanadi Samaha, ${ }^{3}$ and Mira El Chaar ${ }^{1,}{ }^{*}$ \\ ${ }^{1}$ Faculty of Health Sciences, University of Balamand, Beirut, Lebanon \\ ${ }^{2}$ Laboratory Medicine, Makassed General Hospital, Beirut, Lebanon \\ ${ }^{3}$ Laboratory Medicine, Saint Georges University Medical Centre, Beirut, Lebanon \\ "Corresponding author: Mira El Chaar, Faculty of Health Sciences, University of Balamand, P.O Box 166378 Ashrafieh, Beirut 1100-2807, Lebanon. Tel: +961-1562108-9, Fax: \\ +961-1562110, E-mail: mira.elchaar@balamand.edu.lb
}

Received 2017 January 10; Revised 2017 March 14; Accepted 2017 April 27.

\begin{abstract}
Background: Hepatitis B virus (HBV) infection remains one of the major infectious threats to human health. Since the implementation of highly sensitive HBV nucleic acid testing, occult HBV infection (OBI) has been detected. Occult HBV infection is characterized by a positive HBV DNA test with undetectable HBsAg (Hepatits B surface antigen). The prevalence of OBI varies significantly between geographic areas, genotypes, and population depending on the sensitivity of the detection assays used.

Objectives: This project aimed at determining the prevalence of OBI in blood donors from a major blood donor center in Beirut, Lebanon through testing for $4 \mathrm{HBV}$ markers (HBsAg, anti-HBs, anti-HBc and HBV DNA).

Methods: A total of 7437 blood donors were first tested for anti-HBc marker between August 2013 and March 2015; samples positive for anti-HBc were tested for other serological markers and HBV genome. DNA was extracted from $500 \mu \mathrm{L}$ of plasma and tested for HBV DNA using Artus HBV TM PCR Kit assay. All anti-HBc positive samples were tested by nested PCR, targeting the $S$ gene.

Results: This study revealed a 4.6\% prevalence of anti-HBc positive blood donors (341/7437). Among anti-HBc positive blood donors, 21 were HBsAg positive (6.2\%) and 75\% were positive for anti-HBs. The occurrence of occult hepatitis B virus in healthy seropositive blood donors during a 20 month period was very low; only 1 Syrian blood donor ( $n=1 / 341,0.3 \%$ ) was HBsAg negative, HBV DNApositive with anti-HBs level $>1000 \mathrm{mIU} / \mathrm{mL}$.

Conclusions: Our study indicates that HBVDNA is present in a small percentage of HBsAg negative, anti-HBc reactive units. Lebanon has developed its own blood screening strategy, which is to screen for anti-HBc in addition to HBsAg. This is based on HBV prevalence and cost-effectiveness of testing methods. The disadvantage of not implementing nucleic acid testing (NAT) is missing rare blood units from donors in the window period.
\end{abstract}

Keywords: Occult HBV, Prevalence, Lebanon, Blood Donors

\section{Background}

Hepatitis B virus (HBV) infection remains one of the major infectious agent threats to the human health, it is estimated that this virus infects 400 million of the world's population and is considered as one of the most common transfusion-transmitted viral infection (1-5). Occult HBV infection (OBI) was defined by an international workshop held in 2008 as the "presence of HBV DNA in liver (with a viral load of $<200 \mathrm{IU} / \mathrm{mL}$ or undetectable HBV DNA in the serum) of individuals testing hepatitis B surface antigen negative by currently available assays" (6-8). The prevalence of OBI carriers was shown to be more prominent since the introduction of HBV DNA nucleic acid testing (NAT) in blood transfusion centers across all continents with yield varying from $0.1 \%$ to $4.16 \%(2-5,9-22)$.

In 2015, the Lebanese committee of blood transfu- sion, with the approval of the ministry of health implemented a new criterion for HBV blood safety; any anti$\mathrm{HBc}$ (antibody to hepatitis B virus core antigen) positive blood unit triggered an indefinite deferral of donor. This strategy resulted in permanent donor deferral of $3 \%$ $5 \%$. So far, many countries started to implement NAT screening in minipools for all their blood donations along with anti-HBc. Considering that Lebanon is a country of low/medium HBV endemicity, the implementation of NAT is not yet considered.

This study aimed to determine the prevalence of occult HBV in blood donors in Beirut, Lebanon with a testing algorithm for HBV markers including HBsAg (Hepatits B surface antigen), anti-HBs (Antibody to hepatitis B virus surface antigen), and DNA in anti-HBc reactive donors. The outcome of this study was used to support whether or not a decision of implementing HBV NAT in Lebanese blood

Copyright (c) 2017, Hepatitis Monthly. This is an open-access article distributed under the terms of the Creative Commons Attribution-NonCommercial 4.0 International License (http://creativecommons.org/licenses/by-nc/4.0/) which permits copy and redistribute the material just in noncommercial usages, provided the original work is properly cited. 
donor settings is justified.

\section{Methods}

\subsection{Sample Collection}

This cross-sectional study estimated the prevalence of OBI in blood donor samples collected between August 2013 and March 2015. A total of 7437 serum samples were collected consecutively during a 20 month period in the transfusion center of a major hospital in Beirut, Lebanon. The study was approved by the institutional review board of Makassed general hospital. Donors were asked about their age, gender, nationality, and HBV vaccination status.

\subsection{Serological Analysis}

All blood donors were tested for anti-HBc using the ARCHITECT Anti-HBc II chemiluminescent microparticle immunoassay (Abbott Diagnostics, Delkenheim, Germany). Architect HBsAg (Abbott Diagnostics), Hepanostika HBsAg Ultra (BioMerieux, France), and Monolisa ${ }^{\mathrm{TM}}$ Anti-HBs PLUS (Bio-Rad, Costa Mesa CA, USA) were used to test all anti-HBc positive reactive samples for HBsAg and anti HBs, respectively, according to the manufacturers' instructions. HBsAg positive samples were tested for Anti-HBe (Antibody to hepatitis B virus e antigen) with the Cobas anti HBe kit (Roche Diagnostics, Mannheim, Germany).

\subsection{Detection of HBV DNA}

DNA was extracted from $500 \mu \mathrm{L}$ of plasma using the high pure viral nucleic acid kit and eluted in $50 \mu \mathrm{l}$ of elution buffer, according to the manufacturers' instructions (Roche Diagnostics, GmbH, Germany). Two assays were used to detect HBV DNA in anti-HBc positive samples: Artus HBV TM PCR kit (sensitivity of $\leq 3.8 \mathrm{IU} / \mathrm{mL}$ ), targeting the pre-core gene, was used according to the manufacturers' instructions (Qiagen, Hilden, Germany) and an in-house assay using the Platinum PCR kit (Invitrogen, San Diego, USA) was tested in parallel targeting the $S$ gene of HBV using the following primers: HBV-1 (CAACCTCCAATCACTCACCAAC) and HBV-2 (ATATGATAAAACGCCGC AGACAC). Dilutions of WHO international standard plasma sample (NIBSC, Potters' Bar, United Kingdom; 97/746) were tested as assay controls. The $25 \mu \mathrm{L}$ PCR (polymerase chain reaction) reaction included $5 \mu \mathrm{L}$ of purified nucleic acid, 12.5 $\mu \mathrm{L}$ of $2 \times$ reaction mix containing $4 \mathrm{mM} \mathrm{MgSO}_{4}, 1 \mu \mathrm{M}$ of forward and reverse primers HBV-1 and HBV-2, $0.2 \mu \mathrm{M}$ of fluorogenic probe, as previously described (23). The amplification cycle conditions were as follows: a cycle of $95^{\circ} \mathrm{C}$ for 10 minutes, then 50 cycles of $30 \mathrm{sec}$ at $95^{\circ} \mathrm{C}$ and 1 minute at $60^{\circ} \mathrm{C}$. The in house assay sensitivity is $20 \mathrm{IU} / \mathrm{mL}(24)$, however, some samples were quantified below that threshold.
Quantification assays were performed on the CFX96 realtime PCR instrument (Bio-Rad, CA, USA).

\subsection{Nested PCR for the S Gene}

All anti-HBc positive samples were tested by nested PCR, targeting the $S$ gene (494bp) using the Taq DNA Polymerase (Sigma-Aldrich, St. Louis, USA). The outer primers were HBVS1 and HBVS2 and inner primers were HBVS3 and HBVS4 $(25,26)$. The first and second round amplifications were performed in a total volume of $50 \mu \mathrm{L}$, containing $1 \times$ reaction buffer, $0.2 \mathrm{mM}$ dNTPs, $1.5 \mathrm{mM} \mathrm{MgCl}_{2}, 0.4 \mu \mathrm{M}$ of each primer, $0.5 \mu \mathrm{L}$ of Taq DNA polymerase, and $10 \mu \mathrm{L}$ of DNA. The cycle conditions were $95^{\circ} \mathrm{C}$ for 2 minutes, followed by 38 cycles at $94^{\circ} \mathrm{C}$ for 20 seconds, $55^{\circ} \mathrm{C}$ for $30 \mathrm{sec}$ onds, and $72^{\circ} \mathrm{C}$ for 45 seconds. A final 10 minutes elongation step at $72^{\circ} \mathrm{C}$ was performed. Five $\mu \mathrm{L}$ of the amplified product of the first round was used as a template for the second round PCR using HBVS3 and HBVS4 with similar cycle conditions.

\subsection{Statistical Analysis}

In this study, the statistical analysis was done using the SPSS software (version 20). Categorical variables were compared by using the Chi-square exact test. P values less than or equal to 0.05 were considered significant.

\section{Results}

\subsection{Demographic Characteristics of Blood Donors}

A total of 7437 blood donors were included in this study (Table 1), 25\% were voluntary donors and $75 \%$ were replacement donors. The age of the donors ranged from 18 to 67 years with a median of 38 years old. The majority of the donors were Lebanese $(\mathrm{n}=5608 / 7437,75 \%)$ or Syrian ( $\mathrm{n}$ $=1406 / 7437,19 \%), 22$ donors were Palestinian $(n=22 / 7437$, $0.3 \%$ ) and 5 were from different nationalities including Egyptian, Iraqi, Iranian, Turkish, or American ( $\mathrm{n}=5 / 7437$, $0.06 \%$ ). Among the selected blood donors, $96 \%$ were males and $4 \%$ were females. Only 3 individuals confirmed that they were vaccinated for HBV.

\subsection{Serological Characterization of Blood Donors}

Anti-HBc was screened during a 20 month period. There were 341 blood donors who were anti-HBc positive ( $n=341 / 7437,4.6 \%$ ). Among the anti-HBc positive blood donors, 21 were HBsAg positive $(n=21 / 341,6.2 \%$; overall prevalence $0.28 \%$ ).

There was a significant difference in anti-HBc, HBsAg, and anti-HBs prevalence between Lebanese, Syrian, or Palestinian blood donors (Table 2); 1.6\% ( $\mathrm{n}=3 / 184$ ), 11.5\% 
Table 1. Demographic and Serological Characteristics of Blood Donors ${ }^{\mathrm{a}}$

\begin{tabular}{|c|c|}
\hline Variables & Value \\
\hline Duration of study & 20 months \\
\hline Total number of blood donors & 7437 \\
\hline \multicolumn{2}{|c|}{ Demographic Data } \\
\hline Age & Range: 18 - 67 (median: 38 years) \\
\hline \multicolumn{2}{|l|}{ Nationality } \\
\hline Lebanese & $\mathrm{N}=5608(75)$ \\
\hline Syrian & $\mathrm{N}=1406(19)$ \\
\hline Palestinian & $\mathrm{N}=22(0.3)$ \\
\hline \multicolumn{2}{|l|}{ Gender } \\
\hline Female & $\mathrm{N}=7139(96)$ \\
\hline Male & $\mathrm{N}=298(0.04)$ \\
\hline Vaccination & $\mathrm{N}=3(0.04)$ \\
\hline \multicolumn{2}{|c|}{ Serological Data } \\
\hline Anti-HBc positive donors & $\mathrm{N}=341(4.6)$ \\
\hline $\begin{array}{l}\text { HBsAg positive in anti-HBc seropositive } \\
\text { blood donors }\end{array}$ & $\mathrm{N}=21(6)$ \\
\hline $\begin{array}{l}\text { Anti-HBs positive in anti-HBc seropositive } \\
\text { blood donors }\end{array}$ & $\mathrm{N}=236(69)$ \\
\hline
\end{tabular}

(15/130), and 13.6\% ( $n=3 / 22$ ) were HBsAg positive, respectively (Pvalue $<0.05$ ). Fifteen of the HBsAg positive samples were confirmed anti-HBe positive.

The frequency of anti-HBs positive samples among anti-HBc positive/HBsAg negative samples was $80 \%$ ( $\mathrm{n}=$ 256/320). The anti-HBs titer ranged between 10 and 1000 $\mathrm{mIU} / \mathrm{mL}$ with a median of $200 \mathrm{mIU} / \mathrm{mL}(<10 \mathrm{mIU} / \mathrm{mL}$ was considered negative).

\subsection{Molecular Analysis of Anti-HBc Seropositive Blood Donors}

A total of 21 samples were DNA positive; the viral load, quantified by Artus HBV TM PCR kit, ranged from 2 to 1162 $\mathrm{IU} / \mathrm{mL}$ (median of $9.3 \mathrm{IU} / \mathrm{mL}$ ) with $95 \%(\mathrm{n}=20)$ of the samples below 500IU/mL(Figure 1). One sample had a viral load of $1162 \mathrm{IU} / \mathrm{mL}, 5$ samples between 179 and $453 \mathrm{IU} / \mathrm{mL}$ as well as 15 samples between 2 and $48 \mathrm{IU} / \mathrm{mL}$. Fifteen of the 20 HBsAg positive samples had enough volume left to test for HBeAg/anti-HBe and all were anti-HBe positive.

The prevalence of occult HBV (HBsAg negative and NAT positive) in anti-HBc positive samples was 0.3\% (1/320). This unique qPCR positive sample was quantified by Artus HBV TM PCR Kit with a viral load of $4 \mathrm{IU} / \mathrm{mL}$. This sample was found in a 49 year old male Syrian donor who was also antiHBs positive (1047 mIU/mL).
All anti-HBc positive samples were tested by nested PCR. The donor carrying the occult infection was confirmed positive by nested PCR and all samples negative by NAT were also confirmed negative by nested PCR.

Among the HBsAg positive samples, there were some discrepancies between real time PCR and nested PCR assays. One sample was negative for HBV nucleic acid by realtime PCR but positive by nested PCR. In addition, 3 samples were positive for DNA by real-time PCR, however, negative by nested PCR (Figure 2). Two of these samples had a viral load below $10 \mathrm{IU} / \mathrm{mL}$ and 1 sample had a viral load of 1162 $\mathrm{IU} / \mathrm{mL}$.

\section{Discussion}

In this study, the objective was to identify OBI among the deferred blood donors. In order to do so, 7437 blood donors were first tested for anti-HBc during a 20 month period. Month by month the prevalence varied between $2.9 \%$ to $7.2 \%$ with an average of $4.6 \%$. Architect Anti-HBc II assay has a good performance in detecting antibodies to hepatitis B core antigen $(27,28)$, however discrepancies and low predictive value of anti-HBc assays in countries with low HBV prevalence were previously reported (29-33). When the prevalence was measured based on the nationality, 9.2\% $(n=130 / 1406)$ of Syrian and 3.2\% (184/5608) of Lebanese were anti-HBc positive, respectively. A similar prevalence (3.7\%) was observed in Lebanese blood donors in 2005 2006 by El-Zaatari et al. (34). HBV infection in blood donors is often seen in non-Lebanese citizens, as $11.8 \%(n=18 / 152)$ and $6.2 \%(n=106 / 1700)$ of anti-HBc positive samples were HBsAg and anti-HBs positive, respectively, as compared to Lebanese with 1.6\% ( $n=3 / 184)$ and 2.6\% ( $n=148 / 5608)$ (Table 2). All HBsAg positive samples tested were confirmed positive for anti-HBe suggesting that these blood donors were HBV carriers with relatively low viral load as confirmed by DNA quantification (Figure 1). The majority of these HBsAg positive healthy donors are in the low or non-replicative phase of chronic hepatitis $B$ infection and do not require anti-viral therapy.

In a previous study conducted between July 2009 and January 2011, $61 \mathrm{HBsAg}$ positive donors were tested for NAT (35) and when compared to the current study, $21 \mathrm{HBsAg}$ were positive. Both of studies have a comparable distribution of HBV viral load at 2 different periods of time, with a predominance of a low viral load in anti-HBe positive, asymptomatic, blood donors (Figure 1). Therefore implementing a highly sensitive assay for HBV DNA screening in Lebanese blood donors, should be considered to avoid any false negative results. Previous studies have shown that various NAT commercial assays differ in their sensitivity (36-38), this could be associated with various factors such 
Table 2. Comparison of Anti-HBc, HBsAg and Anti HBs Prevalence Between Lebanese, Syrian and Palestinian Blood Donors

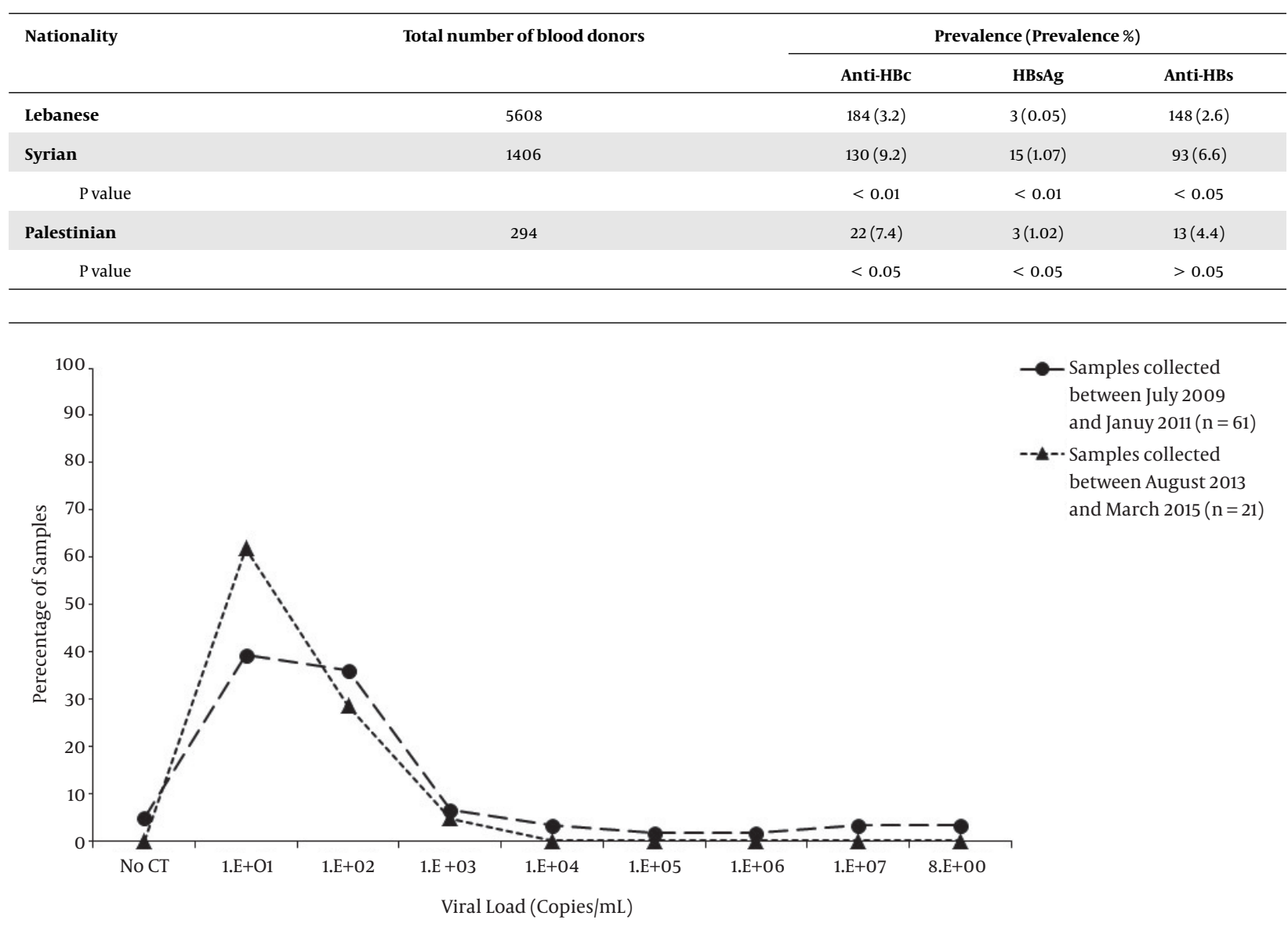

Figure 1. Distribution of HBV Viral Load of NAT Positive Samples Collected at Two Different Time Periods

as: lower input of extracted samples, sample pooling, and mutations in the target genes.

Chaar et al. previously sequenced $42 \mathrm{HBV}$ full genome strains isolated from Lebanon and demonstrated that genotype D strains were the only circulating viruses; in addition various mutations were found in the $S$ and core genes, those were associated with escape detection or disruption of protein synthesis $(35,39,40)$

In this study, the prevalence of OBI in healthy anti-HBc seropositive blood donors was $0.3 \%(n=1 / 341)$, only 1 Syrian donor was an OBI carrier with a high anti HBs level $>1000$ $\mathrm{mIU} / \mathrm{mL}$. Molecular analysis for the detection of any mutation associated with the occult strain was not studied due to plasma volume limitation. A previous Lebanese study conducted in 2007 reported an OBI prevalence of 5.4\% ( $n=$ 11/203), which is higher than what was observed in the current study. However, El-Zaatari et al. detected the circulating viral DNA by nested PCR but failed to detect it by Am- plicor HBV monitor test that had a lower sensitivity (400 genome copies $/ \mathrm{mL}$ ) than the current available commercial assays (34).

A variable prevalence of OBI was reported in few countries of the MENA region (Table 3) such as in Syria (8\%), Iran (0.4\%), Egypt (11.5\% to 17.2\%), and Saudi Arabia (0.4\%) (2, 34, 41-44). The prevalence rates previously stated may differ according to the sensitivity of the NAT assay used in each country. Lebanon has over 1,000,000 Syrian refugees since the start of the Syrian civil war, many epidemics of communicable diseases were reported in this displaced population (45). Among the Lebanese population, the prevalence of HBV is low; only 3 donors were HBsAg positive. The highest prevalence was seen in Syrian as well as Palestinian blood donors (Table 2).

There are many challenges that investigators face but one of them is the follow-up of patients with OBI, which can provide additional information regarding the pa- 


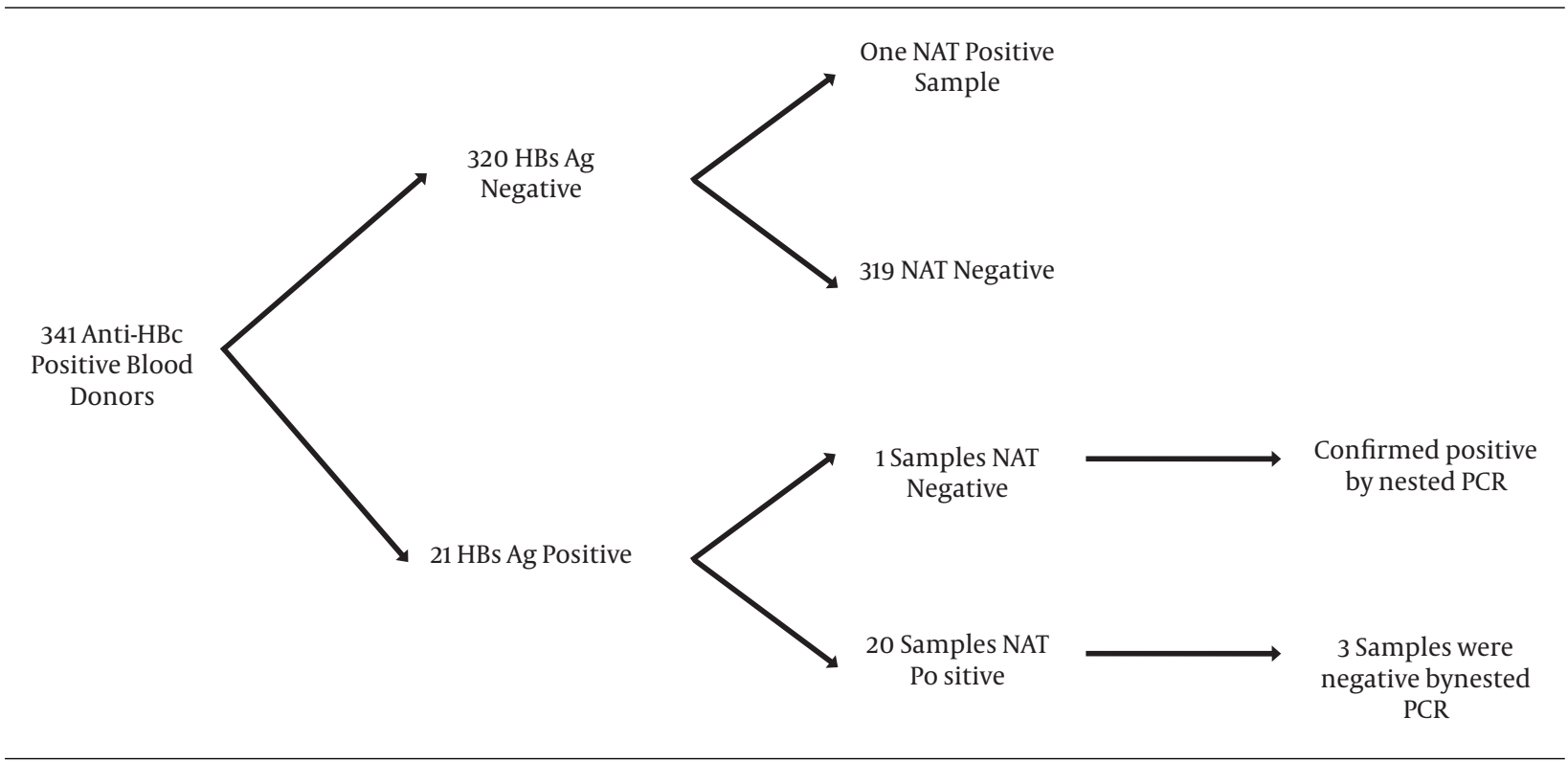

Figure 2. Summary of 341 Anti-HBc Positive Blood Donors Tested for Serology Markers and Nucleic Acid

tients' status. In the current study, we recalled the donor who was positive by NAT and retested him for all HBV serological markers and for the presence of nucleic acid. Three years later, the donor was still positive for anti-HBc and anti-HBs, however he was confirmed negative for HBV nucleic acid using the NAT and nested PCR. Candotti et al. demonstrated, in a look-back study from 25 blood donors who donated 2 to 5 donations over a 20 month period, that the viral load may fluctuate over time and can fail nucleic acid detection (12). Therefore negative NAT does not necessarily indicate that the donor is free of circulating HBV, but possibly that the virus has been replicating at very low level in the liver with occasional release of undetectable viral particles in the circulation. Analysis of HBV DNA in liver biopsy material would be useful to confirm a true OBI.

In this study, we performed both real-time and nested PCR for HBsAg positive and occult samples. Discrepant results were found for some HBsAg positive samples; 3 samples were positive by real time PCR and negative by nested PCR, while 1 sample was negative by real time PCR and positive by nested PCR assays. Failure of detecting HBV DNA using NAT assays was previously reported (25). Inconsistency in the results can be observed when there is low level of circulating HBV or upon the presence of mutations in NAT assay targeted region.

This study has few limitations; the prevalence of occult HBV infection was studied from 1 blood donor center, which does not represent the prevalence in a country. A multicenter study from different Lebanese regions would better represent the country prevalence. In addi- tion, this study did not focus on the prevalence of OBI in the Lebanese versus non-Lebanese communities. A larger sample size from both Lebanese versus Syrians refugees would assure the future threat of HBV on the Lebanese community.

In conclusion, our study has demonstrated that HBV DNA is present in a small percentage of HBsAg-negative, anti-HBc-reactive units. In the current study, $4.6 \%$ of donors were anti $\mathrm{HBc}$ positive while only $0.3 \%$ of them were viremic. Introducing HBV NAT is more favorable in high-endemic areas, where OBI prevalence is high, compared to those with low to medium endemicity of HBV infection. The disadvantage of not implementing NAT testing is the risk of transfusion blood unit from a donor in the window period and in seronegative (anti HBc negative) OBI donors (46). A better strategy of screening should be reconsidered to decrease the number of blood deferrals in Lebanon such as serological testing of both anti HBc followed by anti-HBs or implementation of NAT along with anti-HBc.

\section{Acknowledgments}

We are very grateful to Ms. Ghina Rawas from Makassed general Hospital for collecting serum from blood donors.

\section{Footnotes}

Authors' Contribution: Nour El Banna did the experimental work and wrote part of the manuscript, Tamima 
Table 3. Summary of the Reported Prevalence of Occult Hepatitis B Infection in Anti-HBc Positive Blood Donors in the MENA Region ${ }^{\mathrm{a}}$

\begin{tabular}{|c|c|c|c|c|c|c|c|}
\hline \multirow[t]{2}{*}{ Country } & \multirow{2}{*}{$\begin{array}{l}\text { Period of Sample } \\
\text { Collection }\end{array}$} & \multirow[t]{2}{*}{ Sample Size } & \multicolumn{4}{|c|}{ Prevalence, \% } & \multirow[t]{2}{*}{ Reference } \\
\hline & & & $\begin{array}{l}\text { Anti-HBc positive } \\
\text { samples/ Total } \\
\text { blood donation }\end{array}$ & $\begin{array}{l}\text { HBsAg / Total } \\
\text { blood donation }\end{array}$ & OBI/Anti-HBc + & $\begin{array}{l}\text { OBI/ Total blood } \\
\text { donation }\end{array}$ & \\
\hline Egypt & NS & 3167 & $16.6(n=525)$ & NS & $9.9(n=52)$ & 1.6 & (2) \\
\hline Egypt & 1 month (2005) & $712^{\mathrm{b}}$ & $10.9(\mathrm{n}=78)$ & 1.2 & $11.5(\mathrm{n}=9)$ & 1.26 & (34) \\
\hline Iran & $\begin{array}{l}10 \text { months (2008 - } \\
\text { 2009) }\end{array}$ & 5000 & $9.9(\mathrm{n}=499)$ & NS & $0.4(n=2)$ & 0.04 & (41) \\
\hline Saudi Arabia & $\begin{array}{l}4 \text { months }(2005 \text { and } \\
2007)\end{array}$ & $600^{c}$ & $11.5(n=69)$ & 0.3 & $4.3(\mathrm{n}=3)$ & 0.5 & (42) \\
\hline Syria & 6 months (2011) & 3896 & $12(\mathrm{n}=468)$ & 1.7 & $1(n=5)$ & 0.1 & $(44)$ \\
\hline Lebanon & $\begin{array}{l}12 \text { months (2005 - } \\
\text { 2006) }\end{array}$ & 5511 & $11(\mathrm{n}=608)$ & 0.9 & $4.3(\mathrm{n}=11)$ & 0.2 & (32) \\
\hline Lebanon & $\begin{array}{l}20 \text { months (2013 - } \\
\text { 2015) }\end{array}$ & 7437 & $4.6(\mathrm{n}=342)$ & 0.3 & $0.3(\mathrm{n}=1)$ & 0.01 & current study \\
\hline
\end{tabular}

Abbreviation: NS, The Data Were Not Specified in the Article.

a A total of 253 Anti-HBc positive samples were tested for HBV DNA (Anti-HBc alone' ( $n=203$ ), Anti-HBc./anti-HBs. ( $n=50)$. A total of 355 anti-HBc/Anti-HBs positive samples were not tested for HBV DNA.

${ }^{\mathrm{b}}$ In this study, authors have collected healthy blood donor volunteers, who were referred to National Blood Transfusion Center and mobile blood collection vehicles during September 2005. Samples collected were then tested for HBV NAT.

${ }^{\mathrm{c}}$ The collection started in February 2005, and the second period started in April, 2007. Both periods continued for 2 months.

El Jisr, Hanadi Samaha contributed to the design, data analysis and article revision and Mira El Chaar wrote the manuscript. All listed authors approved the final version of the manuscript.

Competing Interests: The authors declare that they have no competing interests.

Ethics Approval and Consent to Participate: The institutional review board of Makassed general hospital approved the study. Donors signed an informed consent prior to donating blood that include confidentiality of data and results.

Availability of Data and Materials: The data obtained from blood donors are available at Makassed general hospital and the University of Balamand.

Funding/Support: The project was funded by the University of Balamand graduate program research grant

\section{References}

1. Jutavijittum P, Andernach IE, Yousukh A, Samountry B, Samountry $\mathrm{K}$, Thammavong $\mathrm{T}$, et al. Occult hepatitis B infections among blood donors in Lao PDR. Vox Sang. 2014;106(1):31-7. doi: 10.1111/vox.12073. [PubMed: 23931585].

2. Said ZN, Sayed MH, Salama I, Aboel-Magd EK, Mahmoud MH, Setouhy ME, et al. Occult hepatitis B virus infection among Egyptian blood donors. World J Hepatol. 2013;5(2):64-73. doi: 10.4254/wjh.v5.i2.64. [PubMed: 23646231].

3. Seo DH, Whang DH, Song EY, Han KS. Occult hepatitis B virus infection and blood transfusion. World J Hepatol. 2015;7(3):600-6. doi: 10.4254/wjh.v7.i3.600. [PubMed: 25848484].
4. Yuen MF, Lee CK, Wong DK, Fung J, Hung I, Hsu A, et al. Prevalence of occult hepatitis $B$ infection in a highly endemic area for chronic hepatitis B: a study of a large blood donor population. Gut. 2010;59(10):138993. doi: 10.1136/gut.2010.209148. [PubMed: 20675695].

5. Zheng X, Ye X, Zhang L, Wang W, Shuai L, Wang A, et al. Characterization of occult hepatitis B virus infection from blood donors in China. J Clin Microbiol. 2011;49(5):1730-7. doi: 10.1128/JCM.00145-11. [PubMed: 21411575].

6. Hollinger FB, Sood G. Occult hepatitis B virus infection: a covert operation.JViral Hepat. 2010;17(1):1-15. doi:10.1111/j.1365-2893.2009.01245.x. [PubMed: 20002296].

7. Raimondo G, Allain JP, Brunetto MR, Buendia MA, Chen DS, Colombo $\mathrm{M}$, et al. Statements from the Taormina expert meeting on occult hepatitis B virus infection. J Hepatol. 2008;49(4):652-7. doi: 10.1016/j.jhep.2008.07.014. [PubMed: 18715666].

8. Reesink HW, Engelfriet CP, Henn G, Mayr WR, Delage G, Bernier $F$, et al. Occult hepatitis B infection in blood donors. Vox Sang. 2008;94(2):153-66. doi: 10.1111/j.1423-0410.2008.01017.x. [PubMed: 18205672].

9. Allain JP, Candotti D, Soldan K, Sarkodie F, Phelps B, Giachetti C, et al. The risk of hepatitis B virus infection by transfusion in Kumasi, Ghana. Blood. 2003;101(6):2419-25. doi: 10.1182/blood-2002-04-1084. [PubMed: 12393691].

10. Allain JP, Mihaljevic I, Gonzalez-Fraile MI, Gubbe K, Holm-Harritshoj L, Garcia JM, et al. Infectivity of blood products from donors with occult hepatitis B virus infection. Transfusion. 2013;53(7):1405-15. doi 10.1111/trf.12096. [PubMed: 23362802].

11. Brojer E, Grabarczyk P, Liszewski G, Mikulska M, Allain JP, Letowska $\mathrm{M}$, et al. Characterization of HBV DNA+/HBsAg- blood donors in Poland identified by triplex NAT. Hepatology. 2006;44(6):1666-74. doi: 10.1002/hep.21413. [PubMed: 17133474].

12. Candotti D, Opare-Sem O, Rezvan H, Sarkodie F, Allain JP. Molecular and serological characterization of hepatitis B virus in deferred Ghanaian blood donors with and without elevated alanine aminotransferase. J Viral Hepat. 2006;13(11):715-24. doi: 10.1111/j.13652893.2006.00741.x. [PubMed: 17052270]. 
13. El-Zayadi AR, Ibrahim EH, Badran HM, Saeid A, Moneib NA, Shemis MA, et al. Anti-HBc screening in Egyptian blood donors reduces the risk of hepatitis B virus transmission. Transfus Med. 2008;18(1):55-61. doi: 10.1111/j.1365-3148.2007.00806.x. [PubMed: 18279193].

14. Gutierrez-Garcia ML, Fernandez-Rodriguez CM, Lledo-Navarro JL, Buhigas-Garcia I. Prevalence of occult hepatitis B virus infection. World J Gastroenterol. 2011;17(12):1538-42. doi: 10.3748/wjg.v17.i12.. [PubMed: 21472117].

15. Katsoulidou A, Paraskevis D, Magiorkinis E, Moschidis Z, Haida C, Hatzitheodorou E, et al. Molecular characterization of occult hepatitis B cases in Greek blood donors. J Med Virol. 2009;81(5):815-25. doi: 10.1002/jmv.21499. [PubMed:19319945].

16. Kleinman SH, Kuhns MC, Todd DS, Glynn SA, McNamara A, DiMarco A, et al. Frequency of HBV DNA detection in US blood donors testing positive for the presence of anti-HBc: implications for transfusion transmission and donor screening. Transfusion. 2003;43(6):696-704. doi: 10.1046/j.1537-2995.2003.00391.x. [PubMed: 12757519].

17. Liu Y, Li P, Li C, Zhou J, Wu C, Zhou YH. Detection of hepatitis B virus DNA among accepted blood donors in Nanjing, China. Virol J. 2010;7:193. doi: 10.1186/1743-422X-7-193. [PubMed: 20718994].

18. Manzini P, Girotto M, Borsotti R, Giachino O, Guaschino R, Lanteri M, et al. Italian blood donors with anti-HBc and occult hepatitis B virus infection. Haematologica. 2007;92(12):1664-70. doi: 10.3324/haematol.11224. [PubMed: 18055990$]$.

19. Satake M, Taira R, Yugi H, Hino S, Kanemitsu K, Ikeda H, et al. Infectivity of blood components with low hepatitis B virus DNA levels identified in a lookback program. Transfusion. 2007;47(7):1197-205. doi: 10.1111/j.1537-2995.2007.01276.x. [PubMed: 17581154].

20. Stolz M, Tinguely C, Fontana S, Niederhauser C. Hepatitis B virus DNA viral load determination in hepatitis B surface antigen-negative Swiss blood donors. Transfusion. 2014;54(11):2961-7. doi: 10.1111/trf.12694. [PubMed: 24805974].

21. Taira R, Satake M, Momose S, Hino S, Suzuki Y, Murokawa H, et al. Residual risk of transfusion-transmitted hepatitis B virus (HBV) infection caused by blood components derived from donors with occult HBV infection in Japan. Transfusion. 2013;53(7):1393-404. doi: 10.1111/j.15372995.2012.03909.x. [PubMed: 23033944].

22. Zahn A, Li C, Danso K, Candotti D, Owusu-Ofori S, Temple J, et al. Molecular characterization of occult hepatitis B virus in genotype E-infected subjects. J Gen Virol. 2008;89(Pt 2):409-18. doi: 10.1099/vir.0.83347-0. [PubMed: 18198371].

23. Candotti D, Allain JP. Transfusion-transmitted hepatitis B virus infection. J Hepatol. 2009;51(4):798-809. doi: 10.1016/j.jhep.2009.05.020. [PubMed: 19615780].

24. Allain JP, Belkhiri D, Vermeulen M, Crookes R, Cable R, Amiri $A$, et al. Characterization of occult hepatitis $B$ virus strains in South African blood donors. Hepatology. 2009;49(6):1868-76. doi: 10.1002/hep.22879. [PubMed: 19434719].

25. Su H, Zhang Y, Xu D, Wang B, Zhang L, Li D, et al. Occult hepatitis $B$ virus infection in anti-HBs-positive infants born to HBsAg-positive mothers in China. PLoS One. 2013;8(8):e70768. doi: 10.1371/journal.pone.0070768. [PubMed: 23951004].

26. Su HX, Xu DZ, Li D, Zhang JX, Lu J, Choi BC, et al. Heterogeneity analysis of the hepatitis B virus genome in intrauterine infection.J Med Virol. 2005;77(2):180-7. doi:10.1002/jmv.20454. [PubMed: 16121373].

27. Ollier L, Laffont C, Kechkekian A, Doglio A, Giordanengo V. Detection of antibodies to hepatitis B core antigen using the Abbott ARCHITECT anti-HBc assay: analysis of borderline reactive sera. J Virol Methods. 2008;154(1-2):206-9. doi:10.1016/j.jviromet.2008.09.006. [PubMed: 18848582].

28. Seiskari T, Lehtisaari H, Haapala AM, Aittoniemi J. From Abbott ARCHITECT anti-HBc to Anti-HBc II-improved performance in detecting antibodies to hepatitis B core antigen. J Clin Virol. 2010;47(1):100-1. doi: 10.1016/j.jcv.2009.11.010. [PubMed: 19962345].

29. Gessoni G, Beggio S, Barin P, Favarato M, Galli C, Valverde S, et al. Significance of anti-HBc only in blood donors: a serological and virolog- ical study after hepatitis B vaccination. Blood Transfus. 2014;12 Suppl 1:s63-8. doi: 10.2450/2013.0227-12. [PubMed: 23522882].

30. Hourfar MK, Walch LA, Geusendam G, Dengler T, Janetzko K, Gubbe $\mathrm{K}$, et al. Sensitivity and specificity of Anti-HBc screening assayswhich assay is best for blood donor screening? Int J Lab Hematol. 2009;31(6):649-56. doi: 10.1111/j.1751-553X.2008.01092.x. [PubMed: 18673399].

31. Katz L, Strong DM, Tegtmeier G, Stramer S. Performance of an algorithm for the reentry of volunteer blood donors deferred due to false-positive test results for antibody to hepatitis B core antigen. Transfusion. 2008;48(11):2315-22. doi: 10.1111/j.1537-2995.2008.01844.x. [PubMed: 18647367].

32. Schmidt M, Nubling CM, Scheiblauer H, Chudy M, Walch LA, Seifried E, et al. Anti-HBc screening of blood donors: a comparison of nine anti-HBc tests. Vox Sang. 2006;91(3):237-43. doi: 10.1111/j.14230410.2006.00818.x. [PubMed: 16958836].

33. Gessoni G, Beggio S, Barin P, Favarato M, Galli C, Valverde S, et al. Significance of anti-HBc only in blood donors: a serological and virological study after hepatitis B vaccination. Blood Transfus. 2014;12 Suppl 1:63-8. doi: 10.2450/2013.0227-12. [PubMed: 23522882].

34. El-Zaatari M, Kazma H, Naboulsi-Majzoub M, Haidar M, Ramlawi $F$, Mahfoud Z, et al. Hepatitis B virus DNA in serum of 'antiHBc only'-positive healthy Lebanese blood donors: significance and possible implications. J Hosp Infect. 2007;66(3):278-82. doi: 10.1016/j.jhin.2007.04.010. [PubMed:17540476].

35. El Chaar M, El Jisr T, Allain JP. Hepatitis B virus DNA splicing in Lebanese blood donors and genotype A to E strains: implications for hepatitis B virus DNA quantification and infectivity. J Clin Microbiol. 2012;50(10):3159-67. doi: 10.1128/JCM.01251-12. [PubMed: 22785194].

36. Enjalbert F, Krysztof DE, Candotti D, Allain JP, Stramer SL. Comparison of seven hepatitis B virus (HBV) nucleic acid testing assays in selected samples with discrepant HBV marker results from United States blood donors. Transfusion. 2014;54(10):2485-95. doi: 10.1111/trf.12653. [PubMed: 24738835].

37. Kleinman SH, Strong DM, Tegtmeier GG, Holland PV, Gorlin JB, Cousins C, et al. Hepatitis B virus (HBV) DNA screening of blood donations in minipools with the COBAS Ampliscreen HBV test. Transfusion. 2005;45(8):1247-57. doi: 10.1111/j.1537-2995.2005.00198.x. [PubMed: 16078909].

38. Spreafico M, Berzuini A, Foglieni B, Candotti D, Raffaele L, Guarnori I, et al. Poor efficacy of nucleic acid testing in identifying occult HBV infection and consequences for safety of blood supply in Italy. $J$ Hepatol. 2015;63(5):1068-76. doi: 10.1016/j.jhep.2015.06.016. [PubMed: 26116791].

39. Abdelnabi Z, Saleh N, Baraghithi S, Glebe D, Azzeh M. Subgenotypes and mutations in the $s$ and polymerase genes of hepatitis $B$ virus carriers in the West Bank, palestine. PLoS One. 2014;9(12):e113821. doi: 10.1371/journal.pone.0113821. [PubMed: 25503289].

40. Antaki N, Haffar S, Ali Deeb S, Assaad F, Abou Harb R, Zeibane N, et al. High prevalence of HBV genotype D in Syria and the clinical characteristics of hepatitis B e antigen-negative chronic hepatitis B. Epidemiol Infect. 2010;138(1):40-4. doi: 10.1017/S0950268809990288. [PubMed: 19538827].

41. Alizadeh Z, Milani S, Sharifi Z. Occult hepatitis B virus infection among Iranian blood donors: a preliminary study. Arch Iran Med. 2014;17(2):106-7. [PubMed: 24527970].

42. Bamaga MS, Azahar EI, Al-Ghamdi AK, Alenzi FQ, Farahat FM. Nucleic acid amplification technology for hepatitis B virus, and its role in blood donation screening in blood banks. Saudi Med J. 2009;30(11):1416-21. [PubMed: 19882053].

43. Kaminski G, Alnaqdy A, Al-Belushi I, Nograles J, Al-Dhahry SH. Evidence of occult hepatitis B virus infection among Omani blood donors: a preliminary study. Med Princ Pract. 2006;15(5):368-72. doi: 10.1159/000094271. [PubMed: 16888395].

44. Muselmani W, Habbal W, Monem F. Prevalence of "anti-HBc alone" 
among Syrian blood donors. J Infect Dev Ctries. 2014;8(8):1013-5. doi: 10.3855/jidc.3827. [PubMed: 25116667].

45. Burki T. Infectious diseases in Malian and Syrian conflicts. Lancet Infect Dis. 2013;13(4):296-7. doi:10.1016/s1473-3099(13)70089-6.

46. Candotti D, Lin CK, Belkhiri D, Sakuldamrongpanich T, Biswas S, Lin
S, et al. Occult hepatitis B infection in blood donors from South East Asia: molecular characterisation and potential mechanisms of occurrence. Gut. 2012;61(12):1744-53. doi: 10.1136/gutjnl-2011-301281. [PubMed: 22267593]. 